\begin{tabular}{ccc} 
JSI $9(1)(2020)$ & Jurnal Sastra Indonesia \\
UNNES & http://journal.unnes.ac.id/sju/index.php/jsi \\
\hline
\end{tabular}

\title{
DIKSRIMINASI TERHADAP PEREMPUAN DALAM NOVEL SUNYI DI DADA SUMIRAH KARYA ARTIE AHMAD
}

\section{Umi Rahayu ${ }^{\bowtie 1}$ dan Maharani Intan Andalas ${ }^{2}$}

Program Studi Sastra Indonesia, Jurusan Bahasa dan Sastra Indonesia, Fakultas Bahasa dan Seni, Universitas Negeri Semarang, Indonesia

\begin{tabular}{|c|c|}
\hline Info Artikel & Abstrak \\
\hline $\begin{array}{l}\text { Sejarah Artikel: } \\
\text { Diterima Oktober } 2019 \\
\text { Disetujui Februari } 2020 \\
\text { Dipublikasikan Maret } 2020 \\
\text { Keywords: } \\
\text { Dikriminasi, Perempuan, } \\
\text { Kritik Sastra Feminis }\end{array}$ & $\begin{array}{l}\text { Penelitian berjudul "Diskriminasi Terhadap Perempuan dalam Novel Sunyi di Dada } \\
\text { Sumirah karya Artie Ahmad" bertujuan untuk mengetahui diskriminasi terhadap } \\
\text { perempuan dalam novel tersebut. Dalam penelitian ini digunakan teori kritik sastra } \\
\text { feminis dengan metode penelitian kualitatif. Hasil penelitian ini adalah ditemukannya } \\
\text { diskriminasi terhadap perempuan dalam novel Sunyi di Dada Sumirah yakni } \\
\text { stereotip, marginalisasi, dan kekerasan. }\end{array}$ \\
\hline
\end{tabular}

The study entitled "Women Discrimination in the Novel Sunyi di Dada Sumirah by Artie Ahmad" aims to find out women discrimination in the novel. In this study feminist literary criticism theory is used with qualitative research methods. The results of this study are the discovery of women discrimination in the novel Sunyi di Dada Sumirah namely stereotypes, marginalization, and violence.

(C) 2020 Universitas Negeri Semarang

\begin{tabular}{lr}
\hline Alamat korespondensi: & ISSN 2252-6315 \\
Gedung B1 Lantai 1 FBS Unnes & E-ISSN 2685-9599 \\
Kampus Sekaran, Gunungpati, Semarang, 50229 & \\
E-mail: umirahavu @ mail.unnes.ac.id &
\end{tabular}




\section{PENDAHULUAN}

Novel-novel yang membahas perempuan, lahir dari banyak pengarang, baik perempuan maupun laki-laki, baik penulis baru maupun penulis-penulis ternama. Oleh karena itu, penggambaran perempuan dalam karya sastra sangat beragam.

Keragaman tokoh perempuan yang hadir dalam karya sastra tidak hanya berkait dengan nama dan karakter, tetapi juga dengan konflik yang dibangun. Konflik-konflik tersebut kerap membahas ketidakadilan yang dialami tokoh perempuan, stereotip perempuan, dan beberapa membahas kekerasan terhadap perempuan, serta perjuangan perempuan.

Permasalahan ketidakadilan dan kekerasan terhadap perempuan dapat ditemukan dalam beberapa novel, seperti Siti Nurbaya, Ronggeng Dukuh Paruk, dan Ca Bau Kan. Selain ketidakadilan dan kekerasan terhadap perempuan, masalah stereotip perempuan juga muncul dalam beberapa novel di Indoensia, seperti Belenggu dan Gadis Pantai. Bentuk konflik yang lain dalam novel bertokoh perempuan adalah perjuangan perempuan seperti perjuangan perempuan menyetarakan gender, melawan stereotip perempuan, dan menegakkan keadilan. Konflik-konflik tersebut dapat ditemukan dalam novel Saman, Perempuan Berkalung Sorban, dan Bumi Manusia.

Sebagaimana karya seni lain, karya sastra tercipta tidak dengan begitu saja, melainkan melalui proses perenungan dan pembacaan terhadap kondisi-kondisi riil. Oleh karena itu, novel dapat memiliki kesamaan dengan realita.

Menurut data Catatan Tahunan Komnas Perempuan (2018) seperti tahun sebelumnya, kekerasan yang terjadi di ranah privat/personal merupakan kasus paling tinggi dan kasus kekerasan tertinggi adalah kekerasan seksual. Berdasarkan data tersebut pula, diketahui beberapa kekerasan dilakukan oleh pacar, ayah kandung, paman, ataupun di ranah publik dilakukan oleh orang-orang di luar ketiganya.

Selain dari data-data tersebut, bentuk kekerasan lain tercatat dan terpublikasi dalam beberapa media massa. Seperti penganiayaan suami kepada istri (Arjawinangun, 2019), pelecehan seksual di tempat kerja (Rosana, 2019), dan pembedaan upah kerja bagi perempuan (Andreas, 2018).

Dari fenomena-fenomena tersebut, dapat dilihat bahwa kasus yang menimpa perempuan dapat terjadi di mana dan oleh siapa saja. Apabila ditilik lebih lanjut, kasus-kasus tersebut dapat terjadi karena masih adanya ketimpangan gender yang berakibat adanya diskriminasi perempuan.

Dalam Pasal 1 Konvensi PBB mengenai Penghapusan Segala Bentuk Diskriminasi Terhadap Wanita (Konvensi Wanita) berbunyi: "Untuk tujuan Konvensi yang sekarang ini, istilah diskriminasi terhadap wanita berarti setiap pembedaan, pengucilan atau pembatasan yang dibuat atas dasar jenis kelamin, yang mempunyai pengaruh atau tujuan untuk mengurangi atau menghapuskan pengakuan penikmatan atau penggunaan hak-hak asasi manusia dan kebebasan-kebebasan pokok di bidang politik, ekonomi, sosial, budaya, sipil atau apapun lainnya oleh kaum wanita terlepas dari status perkawinan mereka, atas dasar persamaan antara pria dan wanita." (Ihromi, 2000:66)

Dari berbagai permasalahan yang telah dijelaskan, ada upaya-upaya untuk memunculukan gerakan perempuan atau gerakan feminisme. Dalam sastra, gerakan feminisme mendasarkan pada pemikiran feminisme yang menginginkan adanya keadilan dalam memandang eksistensi perempuan, baik sebagai penulis maupun dalam karya sastrakarya sastranya.

Di bidang sastra, feminisme memberikan pengaruh yaitu dengan cara melihat kembali karya sastra yang menggambarkan perempuan dan penulis-penulis yang membicarakan tokoh perempuan yang disebut kritik sastra feminis. Menurut Flax (dalam Wiyatmi, 2012:9), tujuan utama kritik sastra feminis adalah menganalisis relasi gender, hubungan antara kaum perempuan dan laki-laki yang dikonstruksi secara sosial, yang antara lain menggambarkan situasi ketika perempuan berada dalam dominasi laki-laki.

Dari penjelasan tersebut dapat dilihat bahwa kritik sastra feminis dapat digunakan untuk mengungkapkan atau menjelaskan karya sastra perempuan. Salah satu karya sastra yang membicarakan perempuan, selain karya-karya yang telah dijelaskan sebelumnya, adalah novel Sunyi di Dada Sumirah (selanjutnya disingkat $S d D S$ ) yang ditulis oleh Artie Ahmad.

Dalam SDDS, Artie Ahmad menyajikan tiga tokoh utama yang terbagi dalam tiga bagian. Tiap bagian yang disajikan memiliki sudut pandang berbeda sekaligus dalam generasi berbeda tetapi masih dalam satu garis keturunan yakni Sunyi sebagai Cucu, Sumirah sebagai Ibu, dan Suntini sebagai Nenek.

Sunyi sebagai generasi termuda yang berprofesi sebagai mahasiswi, memiliki karakter yang cuek dan pemberani. Dalam novel, ia 
digambarkan senantiasa bersikukuh meminta ibunya agar berhenti menjadi PSK. Selanjutnya, pada sudut pandang kedua, yakni Sumirah, digambarkan sebagai perempuan pekerja seks komersial (PSK) yang memiliki karakter cantik, lemah-lembut, dan pekerja keras. Kemudian, pada sudut pandang ketiga, yakni Suntini, digambarkan sebagai seorang janda yang berprofesi sebagai penjual telur asin. Meski demikian, keahlian Suntini dalam menari membuatnya masuk ke dalam organisasi terlarang pada 65' dan membuatnya mendekam di penjara serta berpisah dari Sumirah.

Dari pejelasan tersebut, dapat dilihat tiga tokoh utama saling terkait dan hal tersebut menyiratkan bahwa masalah perempuan selalu ada meski telah melampaui tiga generasi.

Dalam penelitian ini, peneliti akan menganalisis novel $S d D S$ karya Artie Ahmad karena dalam novel tersebut tampak adanya permasalahan perempuan dan sering kali terjadi dalam kenyataan. Selain itu, sejauh penelusuran peneliti, novel $S d D S$ belum pernah diteliti menggunakan kritik sastra feminis.

Dari latar belakang di atas, peneliti kemudian merumuskan masalah bagaimana diskriminasi terhadap perempuan dalam novel Sunyi di Dada Sumirah karya Artie Ahmad?

Manfaat penelitian ini adalah (1) Penelitian ini diharapkan dapat menambah pengetahuan mengenai studi analisis terhadap sastra di Indonesia, terutama dalam bidang penelitian novel Indonesia yang memanfatkan teori kritik sastra feminis, (2) Penelitian ini diharapkan dapat memberikan sumbangan dalam mengaplikasikan teori sastra dan teori kritik sastra feminis untuk mengungkapkan diskriminasi terhadap perempuan dalam novel SdDS karya Artie Ahmad.

Dalam penelitian ini, peneliti mengacu kepada beberapa hasil penelitian, di antaranya penelitan yang dilakukan oleh Bawole (2003), Windiyarti (2008), Perwitasari (2009), Susanti (2013), Unsriana (2014), Mahfiana (2015), Mustika (2016), Setyorini (2017), Prasetyo (2017), Hidayat (2017), dan Lubis (2018). Wagiran, dkk. (2018).

Berdasarkan penelitian-penelitian tersebut, peneliti menyimpulkan tidak adanya penelitian yang sama dengan penelitian peneliti, yaitu diskriminasi terhadap perempuan dalam novel $S d D S$, yang menggunakan teori kritik sastra feminis.

\section{METODE PENELITIAN}

Metode penelitian yang digunakan dalam penelitian ini adalah metode kualitatif dengan teknik analisis deksriptif. Pendekatan yang dilakukan dalam penelitian ini adalah kritik sastra feminis. Dalam penelitian ini data primer yakni berupa frasa, kata, kalimat, atau paragraf dalam novel SdDS karya Artie Ahmad yang memperlihatkan adanya diskriminasi perempuan dan sikap tokoh-tokoh mengatasi diskriminasi tersebut. Kemudian, data sekunder dalam penelitian ini yakni berupa teks-teks berupa buku-buku, jurnal, artikel, dan sumber penelitian ilmiah lain, yang dianggap terkait dan mendukung.

Selanjutnya, sumber data primer dalam penelitian ini adalah novel Sunyi di Dada Sumirah karya Artie Ahmad terbitan MOJOK, 2018, setebal 297 halaman.

Teknik pengumpulan data yang digunakan dalam penelitian ini adalah teknik pustaka dan catat. Teknik pustaka adalah teknik yang menggunakan sumber-sumber tertulis untuk memperoleh data. Teknik catat berarti peneliti mencatat frasa, kata, kalimat, atau paragraf terhadap data primer, yakni novel $S d D S$ untuk memperoleh data yang diinginkan.

\section{HASIL DAN PEMBAHASAN}

Sesuai dengan rumusan masalah penelitian yang dilakukan peneliti, pada bab ini penulis akan memaparkan diskriminasi terhadap perempuan dalam novel SdDS karya Artie Ahmad

\section{Stereotip \\ Stereotip Terhadap Perempuan}

Mayoritas masyarakat Indonesia menganggap keperawanan seorang perempuan menjadi suatu hal yang "harus" ketika belum menikah. Bahkan di Indonesia ada pula tes keperawanan bagi calon istri TNI, tetapi tidak ada tes keperjakaan bagi suami perempuan TNI.

Tak hanya calon istri anggota TNI, para perempuan yang ingin menjadi anggota TNI pun diharuskan menjalani tes keperawanan. Bentuk tes ini adalah berupa pemeriksaan himen (hymen), yaitu jaringan kulit sangat tipis yang melapisi bukaan vagina perempuan. Wakil Kepala Pusat Kesehatan TNI, Laksamana Pertama Drg. Andriani, Sp.Ort memberikan alasan bahwa, untuk istri prajurit, calon Wan TNI (Wanita Tentara Nasional Indonesia) dan sebagainya harus melakukan tes keperawanan. Ia menganggap apabila perempuan (calon Wan TNI) masih perawan menandakan diri mereka sehat baik jasmani maupun rohani (kumparan.com).

Dari kutipan artikel tersebut, dapat dilihat bahwa keperawanan menjadi hal yang penting dalam konteks masyarakat, dan 
perempuan yang tidak perawan kemudian dianggap tidak sempurna, seperti tidak sehat secara jasmani ataupun rohani.

Dalam novel $S d D S$, juga tergambar adanya persoalan mengenai keperawanan yang menjadi penting bagi perempuan sebelum menikah. Hal itu ditunjukkan dalam kutipan berikut:

"Masih perawan?" Mata perempuan tambun yang dipanggil Susan itu menatapku terus, seolah ada sesuatu di diriku.

"Masih. Segel asli."

"Belum kamu perawanin, Jat?"

"Belum."

"Berapa umurnya?"

"Hampir 25 tahun. Lebih muda dariku beberapa tahun."

"Oh, sudah tidak terlalu muda. Aku sebenarnya lebih tertarik kepada gadis yang lebih muda. Yang masih belasan umurnya. Lima ratus ribu kalau begitu."

"Berengsek! Itu terlalu murah. Badan semulus ini hanya dibeli lima ratus ribu! Ngimpi!" Suara Jatmoko segera meninggi. (hlm. 147)

Kutipan tersebut adalah dialog Susan, sang mucikari dengan Jatmoko, laki-laki yang menjual Sumirah. Saat Jatmoko memperkenalkan Sumirah kepada Susan, pertanyaan awal yang muncul dari Susan adalah tentang keperawanan. Meski setelah itu Sumirah akan bekerja melayani seks, Susan tetap mempertimbangkan perihal perawan dan tidak perawan. Pertanyaan mengenai hal itu pun ditegaskan dengan bertanya kepada Jatmoko apakah ia pernah membuka segel Sumirah.

Penggambaran fenomena tersebut menunjukkan bahwa keperawanan dalam masyarakat dianggap penting. Selain masalah ketidakperawanan, dari kutipan tersebut, tampak pula adanya pandangan tentang perempuan cantik atau mulus berarti perempuan yang menarik sehingga bisa memiliki harga mahal. Seperti yang dikatakan Jatmoko, ia marah ketika Sumirah yang dia anggap memiliki tubuh mulus hanya dihargai lima ratus ribu. Adanya pengertian keliru mengenai gender, memunculkan stereotip terhadap perempuan bahwa perempuan mestinya cantik, mulus, dan perawan. Bahkan jika perempuan dinilai dengan nominal uang, perempuan yang sesuai dengan konstruksi masyarakat tersebut, bisa dinilai lebih mahal.
Dalam novel SdDS tampak pula bahwa stereotip-stereotip tentang laki-laki dan perempuan telah diajarkan sejak kecil, seperti yang diajarkan Suntini kepada Sumirah.

"Lha, iya! Makanya harus selalu bersih kalau jadi perawan, tidak boleh jorok. Nanti perjaka-perjak itu malas nemplek kamu! Ini juga, jangan main di lumpur dan letong, di sana banyak laler yang bawa penyakit..."tambahku sembari membersihkan rambut Mirah yang kotor karena lumpur yang masih melekat. (hlm. 217)

Sadar tak sadar, perkataan-perkataan Suntini seperti Nanti perjaka-perjaka itu malas nemplek kamu! Sebagai candaan sekaligus ancaman terhadap Sumirah yang bermain-main lumpur, telah melahirkan stereotip terhadap perempuan yakni sebagai perempuan harus bersih agar disenangi perjaka-perjaka. Jadi, seolah-olah perempuan berpribadi dan berparas baik hanya untuk mengundang laki-laki.

Ajaran Suntini terhadap Sumirah tersebut pula yang menggambarkan keadaan masyarakat di kenyataan. Sejak kecil, para orang tua, secara turun-temurun telah mengukuhkan stereotip mengenai perempuan harus perawan, bersih, tidak boleh bermain lumpur, dan terlebih perempuan melakukan semua itu agar dinilai baik oleh laki-laki. Tanpa disadari, ajaran-ajaran tersebut terus melekat dan dari generasi ke generasi diajarkan sehingga terciptalah stereotip yang seolah dijadikan sebagai kodrat perempuan.

\section{Stereotip Terhadap Perempuan Pekerja Seks Komersial}

Coleman dan Cressy (Rusyidi, 2018: 308) memandang bahwa pelacuran dapat 'memancing" pria yang sebelumnya tidak tertarik menjadi tertarik pada pelacuran. Pelacuran juga dapat menimbulkan pelabelan negatif terutama kepada anak-anak yang lahir dari ibu yang berpraktik sebagai seorang pekerja seks. Stigma tersebut dapat saja bertahan untuk beberapa generasi sehingga menumbuhkan diskriminasi terhadap pekerja seks dan keturunannya.

Sejalan dengan pendapat Coleman dan Cressy, pada kenyataannya, di kehidupan bermasyarakat, perempuan acap kali dijadikan subjek yang dapat diperlakukan lebih rendah dari laki-laki. Hal tersebut kemudian mempengaruhi pandangan masyarakat terhadap perempuan pekerja seks komersial sebagai pekerja rendahan. Bahkan sebutan sebagai 
wanita tuna susila yang bertujuan sebagai pelembut sebutan, justru sebenarnya lebih merendahkan. Perempuan pekerja seks komersial masih dianggap sebagai jenis pekerjaan, sedangkan wanita tuna susila dapat diartikan sebagai perempuan yang tidak beradab. Akan tetapi, masyarakat hingga pemerintah pun, menganggap PSK sebagai perempuan yang tidak memiliki moral dan menjadi sampah masyarakat, sehingga keberadaan mereka patut dihilangkan.

Dalam novel $S d D S$, stereotip terhadap perempuan menimpa Sumirah yang bekerja sebagai perempuan PSK. Salah satu yang menganggap perempuan PSK sebagai pekerja rendahan dan memiliki derajat rendah adalah Arlen, sahabat Sunyi.

"Memangnya kenapa dengan Ram? Atau pemuda lain? Dia bukan homo dan biseksual kan?" Aku mencoba menggoda Arlen.

"Dia normal. Bahkan sangat normal untuk ukuran seorang pemuda. Kamu sudah tahu latar belakang keluarganya? Ayahnya seorang pengusaha kaya, kakeknya memiliki kedudukan tinggi di pemerintahan, dan ibunya seorang sosialita yang memiliki banyak rekan yang begitulah..."

"Lalu hubungannya denganku apa?" Aku mencoba menekan perasaan yang mulai terasa kurang enak.

"Jangan bodoh kamu, Nyi! Pahamilah posisi dan derajatmu, bandingkan dengan Ram!" Arlen terlihat mulai gusar. (hlm. 30)

Dalam kutipan dialog tersebut, tampak sikap merendahkan derajat seorang pelacur, seperti yang dikatakan Arlen "Jangan bodoh kamu, Nyi! Pahamilah posisi dan derajatmu, bandingkan dengan Ram!" Arlen terlihat mulai gusar. Kalimat tersebut menunjukkan bahwa posisi dan derajat yang dimaksud adalah posisi dan derajat Sunyi sebagai anak perempuan PSK. Selain itu sikap Arlen dalam membandingkan pekerjaan ibu Sunyi dengan pekerjaan keluarga Ram, merupakan sebuah sikap merendahkan. Dalam hal itu Arlen menganggap PSK tidak sederajat dengan pekerjaan lain yang dianggap beradab.

\section{Stereotip Terhadap Perempuan Tahanan Politik}

Menurut Lestariningsih (2011:272) ketersingkiran sosial dialami eks tapol wanita dengan adanya "stigma" yang sebelumnya telah terbangun dan hingga kini masih melekat kuat dalam ingatan masyarakat. Perasaan curiga terhadap kehadiran eks tapol di lingkungan masyarakat sering kali harus mereka terima. Tidak jarang eks tapol menerima cemooh dari masyarakat sekitarnya, dan ada pula yang secara terang-terangan menolak kehadiran mereka.

Ketersingkiran sosial yang dimaskud Lestariningsih, tergambarkan dalam SdDS. Pada novel tersebut, ketersingkiran terjadi karena adanya stereotip negatif dari masyarakat terhadap perempuan tahanan politik. Masyarakat menganggap bahwa tahanan politik adalah aib kampung sehingga keberadaan tahanan politik beserta keluarganya patut disingkirkan.

Orang-orang itu tak akan berani menghina martabat diriku sebagai anak tahanan. .......... Tapi sayang, Emak tak pernah kembali, dia tak pernah pulang, dan orang-orang itu, menjadikan diriku sebagai bahan olok-olok, cacian, dan objek untuk merendahkan derajat seseorang. (hlm. 109)

Dari kutipan tersebut termanisfestasikan adanya diskriminasi terhadap Sumirah. Ia diolok-olok, dicaci, dan direndahkan karena Suntini, sang ibu, menjadi tahanan politik.

Sikap mengolok, mencaci, dan merendahkan adalah bagian dari konstruksi masyarakat yang sejak saat itu, tahun 1965, menjadi tahanan politik berarti menjadi seorang yang memiliki derajat rendah. Bahkan di kampung Sumirah tinggal, masyarakat menganggap tahanan politik sebagai aib dan kotoran. Hal tersebut terdapat dalam paragraf berikut:

Namun, sampai saat ini, aku tak pernah paham, kejahatan Emak itu seperti apa. Para tetangga senantiasa menggunjingnya, mengolok-olok nasib Emak yang begitu jelek tak kepalang tanggung. Bahkan dari mereka yang membencinya lantaran Emak memeperkan tai kebo yang berarti mengoleskan aib di sekujur wajah dusun kami. Bagiku, Emak tak sejahat seperti apa yang mereka bilang. Emak terlalu baik, dia tak pantas dijadikan tahanan. (hlm. 110)

Metafora memeperkan tai kebo dalam paragraf tersebut menunjukkan bahwa seorang tahanan seperti Suntini benar-benar telah 
membuat kampung kotor. Sebutan tai kebo juga merupakan sikap merendahkan karena menyamakan dengan kotoran hewan yang berarti bau, kotor, dan najis.

Anggapan-anggapan masyarakat tersebut menimbulkan tindakan represif seperti perobohan rumah Suntini. Dalam novel, dikisahkan Suntini tak pernah lagi pulang kampung setelah dinyatakan ditangkap. Dan setelah satu tahun tidak kembali, masyarakat beramai-ramai merobohkan rumah Suntini, seperti dalam kutipan berikut:

Setahun setelah kepergian Emak, para tetangga beramai-ramai merobohkan rumah milik Emak. Alasannya sederhana, rumah itu tak lagi dihuni, Emak mungkin tak pernah kembali lagi, sedangkan aku sendiri tinggal di rumah Mbah Wedok. (hlm. 115)

Merobohkan rumah dengan alasan "rumah tak lagi dihuni" merupakan alibi masyarakat agar mereka bisa membuang sisasisa aib di kampung mereka. Hal itu terlihat pada kalimat sebelumnya yakni "Setahun setelah kepergian Emak, para tetangga beramairamai merobohkan rumah milik Emak." Dari kalimat tersebut terlihat masyarakat beramairamai merobohkan rumah setelah Suntini pergi. Apabila dinalar, rumah yang tak dihuni tetapi masih ada keluarga, tidak perlu dirobohkan.

Marginalisasi

Menurut Fakih (1996:13-14), proses marginalisasi yang mengakibatkan kemiskinan, sesungguhnya banyak sekali terjadi dalam masyarakat dan negara yang menimpa kaum laki-laki dan perempuan, misalnya penggusuran, bencana alam atau proses eskploitasi. Namun ada salah satu bentuk pemiskinan atau satu jenis kelamin tertentu, dalam hal ini perempuan, disebabkan oleh gender.

Marginalisasi kaum perempuan tidak saja terjadi di tempat pekerjaan, juga terjadi dalam rumah tangga, masyarakat atau kultur dan bahkan negara. Marginalisasi terhadap perempuan sudah terjadi sejak di rumah tangga dalam bentuk diskriminasi atas anggota keluarga laki-laki dan perempuan. Marginalisasi diperkuat oleh adat istiadat ataupun tafsir keagamaan.

Dalam novel SdDS karya Artie Ahmad, terdapat beberapa bentuk marginalisasi yakni pemecatan, tindakan represif, dan pengucilan. Pemecatan Terhadap PSK yang Hamil
Kehamilan yang dialami PSK acap kali tidak diinginkan oleh mucikari. Hal itu disebabkan karena perempuan hamil dianggap tidak bisa bekerja dengan total. Oleh karena itu, di beberapa instansi atau tempat kerja, perempuan hamil kerap mengalami tindakan diskriminatif seperti diberhentikan dari pekerjaan.

Jatah cuti bagi buruh yang sedang hamil selama 14 minggu dirasa kurang, membuat para wanita buruh pabrik di Cikupa, Tangerang, menuntut pemerintah agar memperhatikan kehidupan buruh wanita (7/10). Menurut Indah, project coordinator dari IndustriALL, tak hanya kasus tewasnya buruh perempuan yang tengah bersalin, banyak pula didapati diskriminasi di lingkungan kerja. Diskriminasi tersebut yakni saat mengetahui buruh hamil, pihak perusahaan memindahkan ke tempat yang tidak layak dan tidak aman. Bahkan ada perusahaan yang langsung memecat begitu tahu buruh itu hamil (Sindonews.com).

Sikap diskriminatif yang dialami buruh perempuan dalam pengakuan Indah tersebut menggambarkan bahwa perempuan hamil dianggap lemah. Adanya pemindahan kerja ke tempat tidak layak hingga adanya pemecatan pun merepresentasikan perempuan hamil tidak diinginkan di dunia kerja. Kasus semacam itu, tergambarkan dalam novel $S d D S$. Dalam novel tersebut, tindakan diskriminatif menimpa Sumirah, PSK yang kemudian hamil di luar keinginan. Mengetahui hal itu, mucikari bernama Susan meminta Sumirah untuk menggugurkan janin dalam kandungan Sumirah agar bisa bekerja seperti biasa.

"Gugurkan sebelum janin itu besar dan kau bisa bekerja seperti biasanya!" Susan naik pitam. Wajahnya yang terkadang menyeramkan itu tampak semakin garang. (hlm. 164)

Dari kutipan tersebut tampak bahwa Susan berpikir perempuan hamil merepotkan dan tidak bisa bekerja sebagaimana perempuan yang sedang tidak hamil. Permintaan Susan tersebut juga menyiratkan adanya ancaman Susan kepada Sumirah, yakni Susan akan memecat Sumirah apabila tidak menuruti kemauannya. Hal itu digambarkan dengan penggambaran mimik wajah Susan yang terkadang menyeramkan tampak semakin garang.

Tindakan Represif terhadap Perempuan Pekerja Seks Komersial 
Tindakan represif merupakan bentuk penindasan yang keras dan kasar. Tidak jarang tindakan represif menimpa kaum minoritas, termasuk terhadap perempuan pekerja seks komersial. Anggapan negatif yang melekat dalam diri perempuan PSK, membuat masyarakat selalu melihat perempuan PSK sebagai seseorang yang hina-dina. Karena anggapan tersebut, menjadikan masyarakat bersikap kasar, sehingga seolah wajar bila ada penindasan terhadap PSK seperti adanya penggusuran atau pengusiran PSK dalam sebuah tempat tinggal.

Dalam novel $S d D S$ karya Artie Ahmad, tindakan represif dapat ditemukan ketika rumah Sumirah dibakar lantaran masyarakat ingin membuat aib. Bahkan orang-orang di sekitar Sumirah tak peduli jika di dalam rumah yang mereka bakar ada anak kecil yaitu Sunyi kecil.

Teriakkan masa itu terdengar. Kaca jendela pecah diiringi ledakan bom Molotov yang dilemparkan seorang warga. Gorden jendela ruang tamu mulai terbakar. Melihat api yang mulai berkobar, aku benar-benar menggigil, terlebih ketika melihat Sunyi mulai menangis. Api menjilati ruang depan. Mulai membakar meja dan kursi yang terbuat dari rotan.

$\mathrm{Aku}$ menangis sembari memeluk Sunyi. Teriakan warga yang marah masih terngiang-ngiang di telinga. Sundal, pelacur, bahkan gundik, itu yang mereka sematkan di diriku tadi. (hlm. 9192)

Dari kutipan tersebut pun tampak pendindasan secara verbal, seperti keluarnya ucapan-ucapan kotor dari mulut masyarakat terhadap Sumirah. Meneriaki Sumirah dengan sebutan sundal, pelacur, dan gundik merupakan tindakan merendahkan perempuan sebagai PSK.

\section{Pengucilan Terhadap Keluarga Pekerja Seks Komersial}

Selanjutnya, pandangan negatif terhadap PSK tak hanya menimpa Sumirah sebagai perempuan PSK, tetapi juga menimpa Sunyi, sang anak. Seperti halnya Sumirah, sejak kecil Sunyi telah mengalami diskriminasi lantaran sang ibu bekerja sebagai PSK.
Dalam hidupku selama ini, aku memang sering mendapatkan pelecehan yang sangat menyakitkan. Sejak kecil lingkungan melecehkanku lantaran aku anak seorang pelacur. Dunia tempatku bernaung seolah-olah tak pernah memberikan keramahan. Manusiamanusia yang ada di sekelilingku melecehkan dengan cara tak ingin bermain, kenal dan cara-cara lain yang menyakiti nurani. Teman-teman di sekolah selalu mengejek. Orang tua mereka melarang anak-anaknya bermain denganku. Tak ada gunanya bermain dengan anak seorang pelacur, lalu pikiran-pikiran dungu yang jahat itu dijadikan alasan untuk mengucilkanku. (hlm. 68)

Kutipan tersebut merepresentasikan sikap pembedaan dari masyarakat sekitar, dan tampak penyebabnya ialah karena Sunyi anak seorang pelacur. Dalam paragraf tersebut terdapat ironi bahwa sejak kecil pun, Sunyi telah mengalami diskriminasi di lingkungannya. Dan dari paragraf itu pula dapat diketahui bahwa stereotip negatif terhadap perempuan PSK pun dipupuk sejak anak-anak. Bahkan anak-anak yang mungkin tidak tahu tentang perempuan PSK, langsung didoktrin bahwa PSK adalah suatu pekerjaan yang buruk dan tidak beradab. Pelarangan orang tua agar tak kenal, mendekati, dan bemain-main dengan Sunyi adalah representasi dari masyarakat mayoritas yang selalu mendiskreditkan minoritas seperti PSK.

\section{Pengucilan terhadap Keluarga Tahanan Politik}

Peristiwa 65' yang menjadi hantu hingga kini, menjadikan kaum minoritas seperti eks tapol, makin tertindas. Pelabelan negatif terhadap para eks tapol sebagai komunis membuat sebagian masyarakat berhati-hati terhadap mereka. Karena kehati-hatian tersebut, masyarakat cenderung menjauhi para eks tapol beserta keluarganya.

Dalam novel SdDS ditemukan adanya pengucilan terhadap Sumirah yang disebabkan Suntini, sang ibu, ditahan. Dikisahkan sebelumnya, Suntini sebagai janda yang menghidupi Sumirah, harus bekerja menjual telur asin keliling kampung. Kala itu, Suntini yang pandai menari, bertemu dengan Dyah, sahabatnya. Di sanalah, Suntini diajak untuk membantu Dyah mengajar menari di organisasi yang Dyah ikuti. Namun, pada peristiwa 65' organisasi yang Suntini masuki dianggap sebagai organisasi terlarang, sehingga Suntini 
diciduk. Sejak saat itu, Suntini tak pernah pulang, dan Sumirah hidup bersama Mbah Wedok, sang nenek. Meski tidak tahu-menahu soal penangkapan Suntini, Sumirah mendapat perlakuan berbeda di lingkungannya lantaran Suntini ditahan secara paksa dan tak pernah pulang.

Di sisi lain, aku juga mengalami serangkaian hal yang menyakitkan. Teman-teman sepermainan yang dulu sering menghabiskan waktu bersamaku, setelah Emak pergi tak mau lagi bermain denganku. Tak sedikit orang tua mereka yang melarang anak-anaknya bergaul denganku. Mereka khawatir kalau suatu hari nanti mereka ketularan bernasib jelek seperti diriku. (hlm. 116)

Dalam paragraf tersebut tampak adanya pengucilan terhadap Sumirah. Pengucilan yang dialami Sumirah yaitu adanya pelarangan oleh orang tua terhadap anak-anak mereka untuk tidak bermain dengan Sumirah, karena mereka khawatir bila suatu hari anak-anak mereka tertular nasib jelek seperti Sumirah.

Apabila dicermati, paragraf tersebut memperlihatkan kesamaan nasib Sumirah dengan Sunyi, yakni diperlakukan berbeda sejak kecil lantaran sang ibu dianggap bermasalah. Sumirah dan Sunyi kecil, mengalami hal serupa yaitu dikucilkan dari lingkungan, orang tua teman-teman Sumirah dan Sunyi kecil melarang bergaul dengan mereka. Alasan pelarangan tersebut pun hampir serupa yaitu ibu keduanya dianggap aib kampung.

\section{Kekerasan}

Menurut Fakih (1996:17), kekerasan adalah serangan atau invasi terhdap fisik maupun integritas mental psikologis seseorang. Kekerasan terhadap sesama manusia pada dasarnya berasal dari berbagai sumber, namun salah satu kekerasan terhadap satu jenis kelamin tertentu yang disebabkan oleh bias gender ini disebut gender-related violence. Pada dasarnya, kekerasan gender disebabkan oleh ketidaksetaraan kekuatan yang ada dalam masyarakat.

Dalam penelitian ini, ditemukan adanya kekerasan dalam novel $S d D S$ yang menimpa tokoh-tokoh perempuan. Kekerasan yang ada dalam novel meliputi pelecehan seksual dan pemaksaan prostitusi.

\section{Pelecehan Seksual}

Sikap merendahkan terhadap perempuan, baik karena jenis kelamin, gender, ataupun jenis pekerjaan, dapat menimbulkan tindakan kekerasan berupa pelecehan seksual. Dalam penelitian ini, ditemukan adanya pelecehan seksual yang disebabkan oleh pekerjaan yaitu pelecehan yang dialami Sunyi karena Sumirah, sang ibu, berprofesi sebagai pekerja seks komersial.

Meski secara perlahan dan meyakinkan, tangan Ram mulai bekerja. Tangan yang tadi meremas tanganku dengan lembut itu mulai berani menjelejahai bagian-bagian tubuhku yang cukup sensitif untuk dipegang lawan jenis. Aku segera menampiknya (hlm. 63)

Dalam cerita tersebut, pelecehan dilakukan oleh Ram, sahabat sekaligus calon pacar Sunyi. Di awal cerita, Ram digambarkan sebagai laki-laki baik hati, peduli, perhatian, dan penuh kasih. Namun, setelah Ram mengetahui Sunyi adalah anak PSK, sikap Ram berubah menjadi laki-laki mesum dan kasar.

Seperti dalam kutipan di atas, Ram dengan sengaja meremas tangan dan menjelajahi bagian-bagian tubuh Sunyi yang sensitif untuk dipegang lawan jenis. Memegang dan menjelajahi bagian tubuh perempuan tanpa seizin pemilik adalah tindakan pelecehan seksual. Dan terbukti pada paragraf lain, bahwa Ram melakukan pelecehan tersebut dikarenakan Sunyi adalah anak PSK. Dalam hal ini, Ram telah merendahkan serta menyepelekan PSK.

"Harga diri? Anak pelacur sepertimu punya harga diri? Sudah sekian lama aku menantikan ini. Tidur denganmu. Memilikimu. Tubuhmu." Ram memainkan keramik kecil berbentuk gajak souvenir dari Thailand yang diletakkan sebagai pemanis meja kecil di sudut kamar. (hlm. 65)

Dari ucapan Ram tersebut, tampak bahwa Ram sangat tidak menghargai profesi PSK sehingga ia bebas memperlakukan Sunyi sebagai perempuan rendahan. Hal itu menunjukkan, PSK adalah profesi yang tidak patut dihormati hingga keturunan-keturunannya, meski keluarga atau keturunan PSK tak berprofesi serupa.

Pemaksaan Prositusi

Segala macam bentuk pemaksaan terhadap seksualitas perempuan merupakan bentuk diskriminasi. Termasuk pemaksaan prostitusi. Dalam pemaksaan prostitusi, prostitute dipaksa menjual tubuhnya entah dengan perasaan senang atau tidak.

Hal ini menggambarkan adanya pemaksaan berhubungan seks yang dipaskakan, 
padahal perempuan memiliki hak atas dirinya, termasuk menolak berhubungan seks bila tidak diinginkan. Pemaksaan dalam prostitusi tak hanya sampai pada pemaksaan melayani pelanggan, tetapi dapat berupa pemerasan dan pembatasan-pembatasan seorang PSK. Seperti dalam paragraf berikut:

Nyaris setiap hari dia berusaha memerasku untuk melayani beberapa pelanggannya dalam satu hari secara bergilir. Dengan begitu uang yang mengalir ke dalam sakunya akan semakin tebal. Aku tahu bahwa harga pasaranku di atas rata-rata temanku yang lain. Meski begitu, pelangganku tak pernah sepi, malah semakin bertambah setiap hari. laku keras, begitulah yang disematkan teman-temanku terhadap diriku. Harga pasaranku semakin hari semakin mahal, hal itu membuat Susan semakin tak ingin melepaskanku. (hlm. 155)

Selanjutnya, pemaksaan prostitusi dalam novel $S d D S$ menimbulkan eksploitasi perempuan. Dalam novel, Sumirah dikisahkan dijebak oleh Bonet, sang mucikari, agar Sumirah bekerja sebagai PSK selama 25 tahun. Dalam hal itu, Bonet memanfaatkan tubuh Sumirah yang sedang mengandung. Bonet menjebak Sumirah dalam dua pilihan yakni memilih 25 tahun bekerja sebagai PSK atau menggugurkan janin dalam perut Sumirah. Pada akhirnya Sumirah memilih menjadi pelacur selama 25 tahun agar janinnya dapat terselamatkan. Akan tetapi, dalam novel, Sumirah diceritakan kurang bisa membaca sehingga ia tidak tahu bahwa surat yang diberikan Bonet adalah surat perjanjian kerja sama antara pelacur dan mucikari yang berat sebelah.

Mendengar pertanyaan Susan, Bonet tersenyum simpul. Dia mengambil surat kontrak dari tanganku, lalu membacanya dengan nada tinggi.

"Dengan ini saya menyatakan bahwa saya bersedia bekerja di bawah asuhan Bonet selama dua puluh lima tahun penuh dengan potongan gaji untuk Bonet setidaknya seperempat dari apa yang saya dapatkan dari klien. Surat kontrak ini dibuat sebagai jaminan atas janin yang sedang saya kandung. Yang bertanda tangan... Sumirah." Bonet mengangkat dagu. "Potongan seperempat bagian itu belum termasuk biaya jasa lantaran aku mencarikanmu klien nantinya. Surat kontrak ini sudah ditandatangani dengan sadar tanpa paksaan. Jadi sah dan tak bisa diganggu gugat." (hlm. 171)

Berdasarkan kutipan tersebut, terlihat sikap Bonet dengan sekehendak hati menindas Sumirah sebagai PSK yang sedang mengandung. Pemanfaatan tubuh Sumirah sebagai bayaran atas kehamilan Sumirah tentu tidak adil. Dalam hal itu, Sumirah harus menanggung semuanya, sementara laki-laki yang menghamili Sumirah entah pergi ke mana dan Bonet tidak mau pula bertanggung jawab.

\section{PENUTUP \\ Simpulan}

Berdasarkan penelitian yang telah dilakukan, dapat disimpulkan bahwa dalam novel SDDS terdapat diskriminasi terhadap perempuan. Diskriminasi terhadap perempuan dalam novel tersebut yakni berupa stereotip, marginalisasi, dan kekerasan. Ketiga diskriminasi tersebut menimpa perempuan dari berbagai usia dan status sosial, seperti pekerja seks komersial (PSK), eks tahanan politik, mahasiswi, janda, dan anak perempuan.

Saran

Berdasarkan penelitian yang telah dilakukan, beberapa saran yang dapat disampaikan oleh penulis antara lain adalah:

1. Penelitian ini dapat dijadikan referensi kajian pustaka bagi penelitian yang sejenis, terutama penelitian tentang diskriminasi terhadap perempuan menggunakan teori kritik sastra feminis.

2. Karena objek dalam penelitian ini belum pernah dikaji sebelumnya, objek penelitian ini diharapkan dapat dikaji dengan teori lain. Teori tersebut misalnya psikologi sastra dan sosiologi sastra, karena dalam objek penelitian tergambarkan adanya kondisi psikologi tokoh dan adanya hubungan sosial-masyarakat yang cukup kental.

3. Penelitian ini dapat menjadi gambaran untuk pembaca bahwa dalam kehidupan, banyak hal yang harus ditelisik lebih jauh agar tidak mudah mendiskriminasi perempuan secara jenis kelamin ataupun peran dalam masyarakat.

\section{DAFTAR PUSTAKA}

Ahmad, Artie. (2018). Sunyi di Dada Sumirah. Yogyakarta: Mojok

Andreas, Damianus. (2018). BPS: Masih Ada Kesenjangan Laki-laki dan Perempuan di 
Ketenagakerjaan. Tirto.id (5 November 2018), diakses pada 15 Mei 2019

Arjawinangun, Komaruddin Bagja. Dapat Diskriminasi, Ini Kisah Buruh Hamil Meninggal di Pabrik. https://metro.sindonews.com (7 Oktober 2015), diakses pada 13 Agustus 2019

Bawole, Merryany T. (2013). Kajian Hak Asasi Manusia Terhadap Perlakuan Diskriminasi Kepada Pekerja Seks Komersial, 21 (3), 12-23

Fakih, Mansour. (1996). Analisis Gender dan Transformasi Sosial. Yogyakarta: Pustaka Pelajar.

Hidayat, M. T., Iswari, R., \& Akhiroh, N. S. (2017). CITRA PEREMPUAN DALAM BERITA KEKERASAN SEKSUAL. Solidarity: Journal of Education, Society and Culture, 6(2), 148-15

Ihromi, Tapi Omas; dkk.. (2000). Penghapusan Diskriminasi Terhadap Wanita.Dalam artikel Hukum, Jender, dan Diskriminasi Terhadap Wanita. Bandung: Penerbit Alumni

Komnas Perempuan. (2018). Tergerusnya ruang aman perempuan dalam pusaran politik populisme: catatan kekerasan terhadap perempuan tahun 2017. https://www.komnasperempuan.go.id/file/p df file/2018/Publikasi/Catatan\%20Tahunan \%20Kekerasan\%20Terhadap\%20Perempuan \%202018.pdf (7 Maret 2018), diakses pada 15 Mei 2019

Lestariningsih, Amurwan Dwi. (2011). Kisah Tapol Wanita di Kamp Plantungan. Jakarta: Kompas Media Nusantara.

Lubis, Fheti Wulandari. (2018). Analisis Diskriminasi Pada Novel "Amelia" Karya Tere-Liye. Journal of Science and Social Research, 1 (1), 53-59.

Mahfiana, Layyin. (2015). Perempuan dan Diskriminasi (Studi Kebijakan Pemerintah Daerah dalam Penghapusan Diskriminasi Terhadap Perempuan). Jurnal Al-'Adl, 8 (2), $110-122$
Mustika. (2016). Diskriminasi Terhadap Beberapa Perempuan dalam Perspektif Feminisme Multikutural: Kajian Terhadap Novel Scappa Per Amore Karya Dini Fitria. Jurnal Poetika. 4 (1), 33-41

Perwitasari, Maria Endah; Retno Hendariningrum. (2009). Analisis Wacana Kritis Feodalisme dan Diskriminasi Perempuan Jawa Dalam Novel Gadis Pantai Karya Pramoedya Ananta Toer. Jurnal Ilmu Komunikasi, 7 (3), 212-227

Prasetyo, Y., \& Haryadi, H. (2017). Kekerasan terhadap Tokoh Perempuan dalam Novel Seperti Dendam Rindu Harus Dibayar Tuntas dan Lelaki Harimau Karya Eka Kurniawan. Seloka: Jurnal Pendidikan Bahasa dan Sastra Indonesia, 6(2), 152-160.

Rosana, Fransisca Christy. Skandal Seks Pejabat BPJS, Siapa Terjebak dan Menjebak?. Tempo.co. (14 Januari 2019), diakses pada 15 Mei 2019

Setyorini, Ririn. (2017). Diskriminasi Gender dalam Novel Entrok Karya Okky Madasari: Kajian Feminisme.Jurnal Desain, 4 (3), 291-297

Susanti, Endah. (2013). Analisis Ketidakadilan Gender Pada Tokoh Perempuan dalam Novel "Kupu-Kupu Malam" Karya Achmad Munif. Jurnal Artikulasi, 10 (2), 713-723

Unsriana, Linda. (2014). Diskriminasi Gender dalam Novel Ginko Karya Junichi Watanabe. Jurnal Lingua Culutra, 8 (1), 40-47

Wagiran, Asep Purwo Yudi Utomo, Dayu Lintang Dwi Cahyani. (2018). Identifikasi Teks Bergenre Cerita Bermuatan Nilai Konservasi. Lingua. 14 (2), 175-189

Windiyarti, Dara. (2008). Pemberontakan Perempuan Bali Terhadap Diskriminasi Kelas dan Gender: Kajian Feminis Novel Tarian Bumi Karya Oka Rusmini.Humaniora, 20 (3), 286-294

Wiyatmi. (2012). Kritik Sastra Feminis: Teori dan Aplikasinya dalam Sastra Indonesia. Yogyakarta: Ombak. 